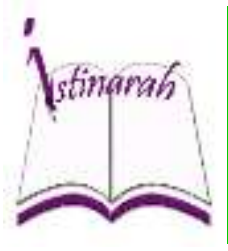

Istinarah: Riset Keagamaan, Sosial dan Budaya, Vol 1 (2), Desember 2019

ISSN :-

$($ Print $)$

(Online)

Tersedia online di http://ecampus.iainbatusangkar.ac.id/ojs/index.php/istinarah/index

\title{
Pola Komunikasi Jarak Jauh Anak dengan Orang Tua Mahasiswa Fakultas Ushuluddin Adab dan Dakwah (FUAD) IAIN Batusangkar
}

\author{
Irsandi Yudha *) \\ Institut Agama Islam Negeri \\ Batusangkar, Sumatera Barat, \\ Indonesia \\ E-mail: \\ irsandiyudha@gmail.com
}

\section{Adripen}

Institut Agama Islam Negeri

Batusangkar, Sumatera Barat, Indonesia

E-mail:

adripen@iainbatusangkar.ac.id

\section{Marhen}

Institut Agama Islam Negeri

Batusangka,

Sumatera Barat, Indonesia

E-mail:

marhen@iainbatusangkar.ac.id

*) Corresponding Author

\begin{abstract}
Abstrak: Masalah utama dalam penelitian ini adalah pola komunikasi jarak jauh antara anak-anak dan orang tua. Pola di sini didefinisikan sebagai bentuk, metode, model komunikasi yang digunakan oleh mahasiswa FUAD IAIN Batusangkar ketika berkomunikasi dengan orang tua mereka, dan juga hambatan komunikasi jarak jauh anak dengan orang tua. Penelitian ini menggunakan metode deskriptif kualitatif. Informan penelitian adalah mahasiswa FUAD IAIN Batusangkar yang tinggal jauh dari orang tua mereka. Teknik pengumpulan data yang peneliti gunakan adalah observasi, wawancara mendalam. Hasil penelitian menunjukkan bahwa pola komunikasi jarak jauh antara anak-anak dan orang tua mahasiswa dari Fakltas Ushuluddin Adab dan Dakwah adalah Pola Komunikasi StimulusRespon di dua arah yang mereka alami dan sama-sama menanggapi pesan apa yang mereka terima, dan di antara mereka tidak ada batasan satu sama lain ketika berkomunikasi.
\end{abstract}

\begin{abstract}
The main problem in this study is the pattern of long-distance communication between children and parents. The pattern here is defined as the form, method, communication model used by FUAD IAIN Batusangkar students when communicating with their parents, and also the barriers to the child's long distance communication with parents. This study used descriptive qualitative method. The research informants were FUAD IAIN Batusangkar students who lived far from their parents. Data collection techniques that researchers use are observation, in-depth interviews. The results showed that the pattern of long-distance communication between children and parents of students of the Fakltas Ushuluddin Adab and Da'wah was a StimulusResponse Communication Pattern in two Directions they experience and equally respond to what message they receive, and between them there is no limit to each other when communicating the point here is that in this communication process both communicators and communicants have the same position, so that the communication process can begin and ends where and whenever.
\end{abstract}

Kata Kunci: Komunikasi, Jarak, Jauh, Orang Tua 


\section{PENDAHULUAN}

Komunikasi merupakan aktivitas dasar yang dilakukan manusia. Tidak ada manusia yang tidak terlibat dalam komunikasi. Menurut Ross dalam Mudjiyanto (2018: 151) komunikasi adalah suatu proses menyortir, memilih dan mengirim simbol-simbol yang sedemikian rupa sehingga dapat membantu pendengar dalam membangkitkan daya respon atau pemaknaan dari sebuah pemikiran yang selaras dengan yang dimaksud komunikator.

Dengan berkomunikasi manusia dapat saling berhubungan satu sama lain baik dalam kehidupan sehari-hari, di rumah tangga, di tempat kerja, di kampus dan dalam masyarakat atau dimana saja manusia berada, tidak ada manusia yang tidak akan terlibat dengan komunikasi. Karena komunikasi merupakan hal mendasar yang sudah dilakukan sejak pertama kali mengenal dunia.

Menurut hasil wawancara yang peneliti lakukan kepada beberapa mahasiswa, komunikasi yang paling intens dilakukan oleh setiap individu ialah ketika mereka berada dengan orang tua mereka, sekedar berbagi informasi dan bertukar pesan tentang permasalahan-permasalahan yang mereka hadapi pada hari itu. Keluarga menjadi tempat berbagi cerita yang dapat menenangkan jiwa ketika mendapatkan suatu persoalan, dengan kata lain keluarga merupakan tempat mengadu bagi anak.

Menurut Harold D. Laswell dalam Suryanto (2015: 231) menggambarkan bahwa komunikasi dalam ungkapan who says what in wich channel to whom with what effect atau dalam bahasa Indonesia berarti siapa mengatakan apa dengan medium apa kepada siapa dengan pengaruh apa. Komunikasi dengan pola atau model diatas menggambarkan bahwa ketika orang tua menyampaikan pesan kepada anaknya haruslah menggunakan media agar timbulnya umpan balik. Dengan demikian pola diatas dapat menjelaskan bahwa dalam komunikasi pesan, media dan umpan balik sangat berpengaruh.

Berkomunikasi dengan keluarga tidak sekedar komunikasi dua arah saja, melainkan harus melalui sebuah pola komunikasi, agar pesan yang ingin disampaikan menjadi efektif. Menurut Permata (2013) Pola Komunikasi bisa 
disebut juga sebagai model, yaitu sistem yang terdiri atas berbagai komponen yang berhubungan satu sama lain untuk tujuan pendidikan keadaan masyarakat

Pola komunikasi sangat berkaitan dengan efektifitas komunikasi yang dijalin antara anak dan orang tua dan begitu sebaliknya orang tua terhadap anaknya. Pola komunikasi merupakan suatu cara atau model yang digunakan agar komunikasi yang terjalin tidak berhenti di situ saja atau dalam artian lain dapat menimbulkan effek bagi keduanya.

Berkomunikasi dengan jarak dekat dan jarak jauh memiliki perbedaan walaupun masa sekarang sudah dilengkapi dengan teknologi yang canggih, seperti VideoCall, Aplikasi Chatting dll. Berkomunikasi dengan jarak dekat bisa mengabaikan frekuensi waktu, pesan yang disampaikan dan intensitas pertemuan tanpa menggunakan media sebagai perantara. Sedangkan berkomunikasi dengan jarak jauh, media yang berperan penting dalam komunikasi ini, media sebagai sarana utamanya, tanpa media komunikasi jarak jauh tidak akan ada. Berkomunikasi jarak jauh menyebabkan pengungkapan perasaan berkurang, terbatasnya waktu komunikasi membuat kesempatan yang ada untuk saling menghubungi juga sangat kurang, pesan yang disampaikan menjadi tidak maksimal, dan semua permasalah tidak tersampaikan.

Ketidakhadiran orang tua setiap saat dan setiap waktu akan menyebabkan permasalahan yang terjalin. Dan bahkan dapat menjadi salah satu alasan banyaknya permasalahan-permasalahan yang terjadi di kalangan mahasiswa karena kurangnya berinteraksi dengan orang tua dikarenakan jarak yang jauh, dan sosok orang tua yang biasa menjadi tempat mengadu sudah jarang ditemui.

Kegagalan komunikasi menyebabkan hal yang fatal, dan dapat menjadi penyebab utama frustasi khususnya bagi anak perantauan yang jarang bertemu orang tua, seperti banyaknya kasus mahasiswa yang hamil di luar nikah, bunuh diri di kamar kos dan bahkan menghilang tanpa kabar. Hal ini dipicu oleh berbagai macam hal, dan orang tua sangat berperan penting ketika masalah ini muncul.

Supaya lebih terarahnya 
pembahasan dalam penelitian ini, maka peneliti memfokuskan penelitian ini pada pola komunikasijarak jauh anak dan orang tua mahasiswa FUAD IAIN Batusangkar yang berada jauh dari orang tua.

\section{METODE}

Penelitian yang dilakukan menggunakan jenis penelitian deskriptif kualitatif. Penelitian kualitatif adalah riset yang bersifat deskriptif dan cenderung menggunakan anlisis dengan pendekatan induktif, proses dan makna (perspektif subjek) lebih ditonjolkan dalam penelitian kualitatif (Rahmat, 2009: 1).

Menurut Bog dan Taylor dalam Moloeng (2016: 4) mendefenisikan metodologi kualitatif sebagai prosedur penelitian yang menghasilkan data deskriptif berupa kata-kata tertulis atau lisan dari orang-orang dan perilaku yang dapat diamati. Menurut Moleong (2016:6) penelitian kualitatif adalah penelitian yang bermaksud untuk memahami fenomena tentang apa yang dialami oleh subjek penelitian, mialnya perilaku, persepsi, motivasi, tindakan, dll., secara holistik, dan dengan cara deskriptif dalam bentuk kata-kata dan bahasa, pada suatu konteks khusus yang alamiah dan dengan memanfaatkan berbagai metode alamiah.

Dalam penelitian deskriptif kualitatif, penulis berusaha memahami dan menjelaskan perilaku manusia dalam situasi tertentu. Tujuan penelitian ini utnuk mengetahui interprestasi atas perilaku seseorang, sehingga diharapkan mampu memaparkan gambaran mengenai pola komunikasi jarak jauh anak dan orang tua.

Menurut Sugiyono (2007: 103) sumber data dalam penelitian berupa data yang diambil langusng dari objek penelitian antara lain: Data Primer (premier-sources), mencari data langsung ke lapangan dengan sumber penelitian ini adalah mahasiswa FUAD IAIN Batusangkar yang berada jauh dengan orang tuanya, dan sudah bertempat tinggal berbeda dari orangtua selama 2 tahun, dan Data Sekunder (secondary-sources). Yaitu dengan mencari referensi buku-buku jurnal yang berkaitan dengan pola komunikasi.

Dalam penelitian kualitatif, sumber data primer dan teknik 
pengumpulan data lebih banyak pada observasi (observation non partisipan) dan wawancara mendalam (in dept interviem). Metode pengumpulan data yang utama dalam penelitian kualitatif ada tiga macam, yakni pengamatan partisipasi, wawancara mendalam dan dokumentasi (Prestowo, 2010). Dalam penelitian ini penulis melakukan observasi pada mahasiswa Fakultas Ushuludin, Adab dan Dakwah IAN Batusangkar, mewawancarai mahasiswa yang berkaitan langusung dengan tema penelitian serta pengumpulan dokumentasi sebagai bukti telah melakukan penelitian.

Teknik penentuan subjek dalam pengumpulan data dalam penelitian ini yaitu memakai snowball sampling. Snowball sampling adalah teknik penentuan sampel yang mula-mula jumlah kecil, kemudian membesar. Dalam penentuan sampel, pertamatama dipilih satu atau dua orang, tetapi karena dengan dua orang ini belum merasa lengkap terhadap data yang diberikan, maka peneliti mencari orang lain yang di pandang lebih tahu dan dapat melengkapi data yang diberikan oleh dua orang sebelumnya. Begitu seterusnya, sehingga jumlah sampel semakin banyak (Sugiyono, 2007: 125).

Menurut Sugiyono (2013: 245) analisa data dalam penelitian kualitatif dilakukan sejak sebelum memasuki lapangan, selama di lapangan dan setelah di lapangan. Dikatakan juga bahwa data sebelum memasuki lapangan dilakukan terhadap data hasil studi pendahuluan, atau data sekunder yang akan digunakan untuk menentukan fokus penelitian.

Sedangkan Miles dan Husberman dalam Sugiyono (2013: 246) aktivitas analisis data yaitu data reduction, data display dan conclusion drawing/ verfication.

Reduksi Data. Disini peneliti mengumpulkan, merangkum, memilih informasi- informasi yang pokok, memfokuskan pada informasi yang penting, dicari tema dan polanya. Dengan demikian data yang telah direduksikan memberikan gambaran yang lebih jelas tentang Komunikasi Interpersonal Hubungan Jarak Jauh Anak dan Orang Tua.

Penyajian Data. Penyajian hasil penellitian ini dipaparkan deskriptif berdasarkan temuan di lapangan dengan bahasa khas dan pandangan 
emik informan agar mudah dipahami oleh pembaca. Melakukan interprestasi data yaitu menginterprestasi apa yang telah diinterperstasi oleh informan terhadap masalah yang diteliti.

Penarikan Kesimpulan. Pada tahap ini peneliti melakukan interpretasi data sesuai dengan konteks permasalahan dari tujuan penelitian. Dari interpretasi yang dilakukan akan diperoleh kesimpulan dalam jawaban masalah penelitian.

\section{HASIL DAN PEMBAHASAN}

Dari hasil penelitian telah di dapat dari dua puluh empat informan anak (mahasiswa) yang semuanya terdaftar sebagai mahasiswa Fakultas Ushuluddin Adab dan Dakwah dari berbagai jurusan yang tinggal jauh dari orang tua. Pengumpulan data dengan metode observasi dan wawancara penulis menggunakan pedoman wawancara sebagai panduan untuk menanyakan aspek yang akan di ungkap terkait dengan pola komunikasi jarak jauh anak dengan orang tua mahasiswa FUAD IAIN Batusangkar.

Komunikasi jarak jauh anak dengan orang tua mahasiswa FUAD IAIN Batusangkar sangat baik karena baik orang tua maupun anak atau sebaliknya seringkali sebagai orang yang memulai percakapan. Selanjutnya media yang sering digunakan oleh mahasiswa FUAD IAIN Batusangkar ketika berkomunikasi dengan orang tuanya adalah melalui telephon ( $\mathrm{Hp})$, media yang digunakan ketika berkomunikasi berdampak efektif ketika anak berada jauh dari orang tuanya, dimana orang tua bisa memantau segala aktifitas yang dilakukan anaknya. dan baik orang tua maupun anak seringkali menyampaikan feedback yang diberikan pada saat itu juga.

\section{Pola Komunikasi Stimulus-Respon}

Berdasarkan data yang peneliti peroleh, berkaitan dengan pola komunikasi S-R anak dengan orang tua mahasiswa FUAD IAIN Batusangkar, dapat dijelaskan bahwa mahasiswa selalu merespon pesan yang di sampaikan oleh orang tua dan begitu juga orang tua, tetapi berkomunikasi lewat media belum memuaskan hasrat mahasiswa untuk sekedar melepas rindu.

Berdasarkan penjelasan di atas ditemukan bahwa antara orang tua dan anak saling berbagi informasi terkait hal 
yang sedang mereka lakukan satu sama lain dan juga merespon setiap pesan yang diperoleh baik dari orang tua kepada anak dan anak kepada orang tua.

"Saya selalu merespon pesan yang di sampaikan oleh orang tua. Berkomunikasi lewat media sudah memuaskan hasrat saya untuk melepas rindu dengan beliau. Saya selalu mengabari orang tua saya jika akan berpergian ke luar kampus, tetapi saya tidak pernah mengabari jika akan mengikuti kegiatan kampus dan akan mengikuti ujian semester. Orang tua saya selalu bertanya mengenai apa saja yang saya lakukan di kampus dan mengabari apa saja yang terjadi di kampung"

"Saya merespon langsung pesan yang di sampaikan oleh orang tua saya. Ketika setelah melakukan komunikasi dengan orang tua belum memuaskan hasrat saya untuk sekedar melepas rindu. Saya selalu mengabari orang tua saya jika mengikuti aktifitas di kampus, akan mengikuti ujian semester dan jika berpergian keluar kampus. Orang tusa selalu bertanya apa saja yang saya lakukan di kampus dan memberikan informasi apa yang terjadi di kampung"

\section{Pola Komunikasi ABX}

Berdasarkan data yang diperoleh, mahasiswa jarang mendapat tekanan dari orang tua agar selalu menuruti keinginan orang tua, namun orang tua hanya mengarahakan dan tidak pernah bertanya masalah bagaimana sikap yang diperbuat oleh mahasiswa setiap hari.

Berdasarkan observasi yang peneliti lakukan, mahasiswa memilih kuliah diluar kota untuk menambah wawasan dan pengalaman baru di tempat yang baru, bukan sebuah paksaan dari orang tua untuk melanjutkan perkuliahan di luar kota, mahasiswa di sarankan untuk rajinrajin melaksanakan perkuliahan saat jauh dari orang tua.

Berdasarkan penjelasan diatas, ditemukan bahwa antara orang tua dan anak tidak ada keterpaksaan dalam melakukan suatu hal untuk menuruti setiap perintah dari orang tua, namun hanya menyuruh agar selalu rajin dan aktif dalam melaksanakan masa perkuliahan.

"Orang tua saya tidak selalu menekan saya agar selalu mengikuti 
keinginannya, beliau sering terkadang hilang dan masalah pulsa mengarahkan saya, dan juga menyuruh yang tidak mencukupi untuk saya agar rajin menuntuk ilmu dan melakukan panggilan melalui aktifitas di kampus. Masalah sikap telephone.

orang tua saya jarang menanyakan hal

Berdasarkan penjelasan diatas, itu kepada saya". dapat disimpulkan bahwa hambatan

"Orang tua saya tidak pernah komunikasi jarak jauh anak dengan menekankan saya agar selalu orang tua mahasiswa FUAD IAIN mnegikuti kehendaknya, namun dia hanya mengarahkan saya. Orang tua saya juga sering menyuruh saya agar rajin-rajin kuliah dan tidak pernah menanyakan sikap saya"

\section{Hambatan Komunikasi}

Berdasarkan data yang diperoleh, berkaitan dengan hambatan Komunikasi Jarak jauh anak dengan orang taua mahasiswa FUAD IAIN Batusangkar ditemukan ada beberapa hambatan. Hambatan komunikasi jarak jauh anak dengan orang tua mahasiswa FUAD IAIN Batusangkar yaitu singnyal, pulsa, keadaan geografis, kegiatan di kampus dan keseharian di luar kampus.

Berdasarkan observasi yang peneliti lakukan terdapat beberapa hambatan yang terjadi anatara anak dengan orang tua yaitu waktu yang tidak ada untuk melakukan komunikasi, masalah sinyal yang Batusangkar yaitu sinyal yang terkadang tidak bagus, pulsa yang tidak mencukupi untuk melakukan komunikasi, keadaan geografis yang mengakibatkan sinyal telephon mejadi terhalang, kegiatan kampus yang padat dan keseharin yang mengakibatkan jarangnya komunikasi anatara anak dan orang tua.

Berdasarkan data wawancara penulis dengan mahasiswa FUAD IAIN Batusangkar yang berada jauh dari orang tuanya terkait dengan pola komunikasi jarak jauh, dapat ditemukan bahwa komunikasi jarak jauh anak dengan orang tua mahasiswa FUAD IAIN Batusangkar sangat baik karena baik orang tua maupun anak atau sebaliknya seringkali sebagai orang yang memulai percakapan. Selanjutnya media yang sering digunakan oleh mahasiswa FUAD IAIN Batusangkar ketika 
berkomunikasi dengan orang tuanya atau dua orang siswa yang sudah adalah melalui telephon ( $\mathrm{Hp})$, media terpuaskan hasrat mereka untuk yang digunakan ketika berkomunikasi melepas rindu.

berdampak efektif ketika anak berada

Dan tidak adaya paksaan untuk jauh dari orang tuanya, dimana orang mengikuti kehendak dari orang tua. tua bisa memantau segala aktifitas yang Setiap pesan yang di sampaikan dilakukan anaknya. dan baik orang tua mereka saling merespon satu sama lain, maupun anak seringkali menyampaikan dan menjadikan komunikasi tidak feedback yang diberikan pada saat itu hambar atau seperti percakapan antara juga.

Hal ini sesuai dengan teori yang menyatakan bahwa komunikasi harus memuat tiga unsur yaitu pesan, media dan umpan balik. Harold D. Laswell dalam Suryanto (2015: 231) menggambarkan bahwa komunikasi dalam ungkapan who says what in wich channel to whom with what effect atau dalam bahasa Indonesia berarti siapa mengatakan apa dengan medium apa kepada siapa dengan pengaruh apa.

Berdasarkan penjelasan di atas dapat di simpulkan bahwa pola komunikasi yang terjadi antara anak dengan orang tua mahasiswa Fakultas Ushuluddin Adab dan Dakwah adalah mereka selalu merespon pesan yang di sampaikan oleh orang tua mereka pada saat itu juga, berkomunikasi lewat telepon belum memuaskan hasrat mereka untuk melpas rindu, hanya satu orang yang tidak mengenali. Sehingga dari hasil temuan peneliti dari teori yang ditemukan, pola komunikasi jarak jauh anak dengan orang tua mahasiswa FUAD IAIN Batusangkar yaitu pola komunikasi stimulus-respon dengan dua arah, dua arah disini maksudnya antara kedua belah pihak saling berbagi informasi dan saling merespon pesan yang diterima.

\section{KESIMPULAN}

Berdasarkan hasil penelitian tentang pola komunikasi jarak jauh anak dengan orang tua mahasiswa Fakultas Ushuluddin Adab dan Dakwah dapat disimpulkan sebagai berikut:

Pola komunikasi jarak jauh yang terjadi pada mahasiswa FUAD IAIN Batusangkar dengan orang tua mereka adalah pola komunikasi Stimulus- 
Respon dan komunikasi dua arah, dimana antara anak dan orang tua sama-sama memberikan pesan tentang hal yang mereka alami dan sama-sama merespon apa pesan yang mereka terima, dan di antara mereka tidak ada batasan satu sama lain ketika berkomunikasi maksudnya tidak ada orang yang berperan sebagai komunikator maupun komunikan.

Hambatan komunikasi jarak jauh yang terjadi di antara mereka adalah hambatan waktu yang tidak sesuai dengan keinginan, geografis yang menyebabkan gangguan bagi alat komunikasi yang mereka gunakan, dan psikologis mereka yang sedikit sibuk dalam mengikuti kegiatan perkuliahan.

\section{REFERENSI}

Moleong, I.J. 2006, Metodologi Penelitian Kualitatif. Bandung: PT Remaja Rosdakarya

Mudjiyanto, Bambang. (2018). Pola Komunikasi Siswa Tuna
Rungu Di Sekolah Luar Biasa

Negeri Bagian B Kota Jayapura. Jurnal Studi Komunikasi dan Media. 151165

Permata, Sintia. (2013). Pola Komunikasi Jarak Jauh Antara Anak Dengan Orang Tua. Journal Acta Diurna. Vol.II No.I

Rakhmat, Jalaludiin, 2007, Psikologi Komunikasi, Bandung, PT Remaja Rosdakarya,

Sugiyono. 2007. Metode Penelitian Pendidikan. Bandung: $\mathrm{Cv}$ Alfabeta.

2013. Metode Penelitian Kuantitatif dan Kualitatif dan $R \& D$. Cet 18 Bandung: CV. Alfabeta

Suryanto. (2015). Pengantar Ilmu Komunikasi. Bandung: CV Pustaka Setia 